ZOOLOGIA 31 (3): 281-284, June, 2014

http://dx.doi.org/10.1590/S1984-46702014000300011

\title{
A new species of Arapona from Peru (Hemiptera: Cicadellidae: lassinae: Gyponini)
}

\author{
Alexandre Cruz Domahovski \& Rodney Ramiro Cavichioli
}

\begin{abstract}
Departamento de Zoologia, Universidade Federal do Paraná. Caixa Postal 19020, 81531-980 Curitiba, PR, Brazil. E-mail: domahovskiac@yahoo.com.br; cavich@ufpr.br
\end{abstract}

\begin{abstract}
Arapona furcata sp. nov. is described and illustrated based on a male specimen from Peru, department of Madre de Dios. This species can be recognized by the following features: 1) styles without a concavity on the ventral margin; 2) aedeagus robust and with a pair of long and slender preatrial processes; and 3) aedeagus with two apical processes, each with a sharp and hook-like apex. A key to the three known species of the genus is added.
\end{abstract}

KEY WORDS. Arapona devisa; Arapona vallea; identification key; Neotropical region; taxonomy.

DeLong (1979) described Arapona with two new species: A. vallea DeLong, 1979 (from Panama), which was designated as the type-species, and A. devisa DeLong, 1979 (from Peru). Both were described from a single male. The genus was characterized by DeLong (1979) as follows: 1) head broadly rounded anteriorly; 2) disk of crown semicircular; 3 ) anterior margin of crown thin; 4) ocelli nearer anterior than posterior margin; 5) pronotum declivous; and 6) aedeagus with paraphyses (atrial processes). According to DeLong (1979), the species of Arapona and Gypona Germar, 1821 are similar and are closely related to Clinonella Delong \& Freytag, 1971, based on the large slope of the pronotum.

After studying a male specimen collected in Peru, we propose a new species, Arapona furcata sp. nov. The male was collected by light trap at the department of Madre de Dios. A key to the three known species of the genus is added.

\section{MATERIAL AND METHODS}

The studied specimen is deposited at the Museo de Historia Natural, Universidad Nacional Mayor de San Marcos, Lima (MUSM). The terminology follows mainly Young (1968, 1977), except for the head structures (Hamilton 1981, MejDaLani 1998) and leg chaetotaxy,(Rakitov 1997). The techniques for preparation of male genital structures follow OMAN (1949) with some modifications described by CAVICHIOLI \& TAKIYA (2012). Label data are given inside quotation marks with a reversed slash $(\backslash)$ separating lines on the labels and a semicolon separating different labels.

\section{Arapona furcata sp. nov. Figs 1-13}

Male holotype: total length $8.00 \mathrm{~mm}$. Head and thorax. Head (Fig. 1) slightly produced, with median length of crown almost one-half interocular width and three-tenths transocular width; anterior margin broadly rounded, slightly longer medially than near eyes. Disk of crown almost smooth, with slightly marked and irregular striae, located near eyes. Ocelli located in front of imaginary line between anterior angles of eyes, closer to eyes than median line and closer to anterior than to posterior margin of crown. Head (Fig. 3), in lateral view, with margin of crown angulate and thin, with three carinae. Head (Fig. 2), in frontal view, with frons and clypeus slightly pubescent, with short and fine setae; frons slightly depressed medially; muscle impressions distinct; epistosmal suture incomplete. Clypeus continuous with profile of frons. Frontogenal suture reaching antennal ledges. Thorax with width between humeri slightly longer than transocular width, lateral pronotal margins slightly convergent anteriorly. Pronotum (Fig. 3), in lateral view, declivous, with disk finely striate except on anterior third. Mesonotum (Fig. 1) slightly rugose. Forewing 3.5 times longer than wide; venation distinct and elevate; three closed anteapical cells; central cell with transverse vein; five apical cells; apex rounded; appendix reduced. Hind legs with femoral setal formula 2:2:1; tibial row AD without intercalary microsetae; row PD with approximately twice as many macrosetae as $\mathrm{AD}$; first tarsomere as long as length of two distal tarsomeres combined and with two parallel rows of small setae on plantar surface.

Male terminalia. Sternite VIII (Fig. 5), in ventral view, with lateral margins converging posteriorly, trapezoidal, with posterior margin slightly extended medially. Pygofer (Fig. 6), in lateral view, triangular, 2.5 times longer than basal width, apex subacute; macrosetae distributed at apical half. Valve fused with pygofer, twice wider than long. Subgenital plates (Fig. 7), in ventral view, long and narrow, nearly half of pygofer length, rounded apex with tuft of long and thin setae on dorsal surface. Connective (Fig. 8), in dorsal view, X-shaped, with rami

2014 Sociedade Brasileira de Zoologia | www.sbzoologia.org.br | www.scielo.br/zool All content of the journal, except where identified, is licensed under a Creative Commons attribution-type BY-NC. 

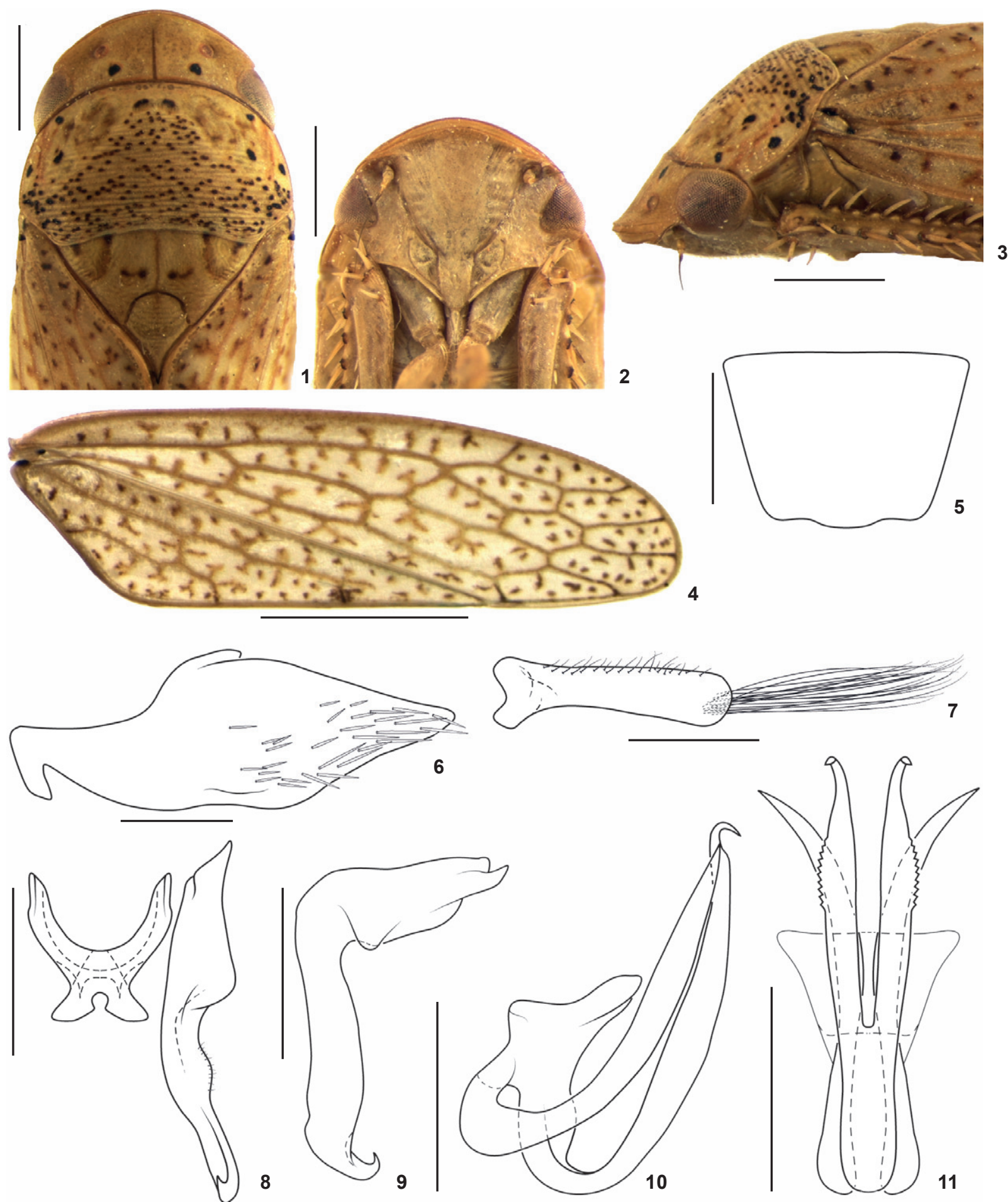

Figures 1-11. Arapona furcata sp. nov., male holotype: (1) head and thorax, dorsal view; (2) head, frontal view; (3) head and thorax, lateral view; (4) forewing; (5) sternite VIII, ventral view; (6) pygofer, lateral view; (7) subgenital plate, ventral view; (8) style and connective, dorsal view; (9) style, lateral view; (10) aedeagus, lateral view; (11) aedeagus, posterior view. Scale bars: 1-2 = 1.0 mm, 4 $=2.0 \mathrm{~mm}, 5-11=05 . \mathrm{mm}$. 


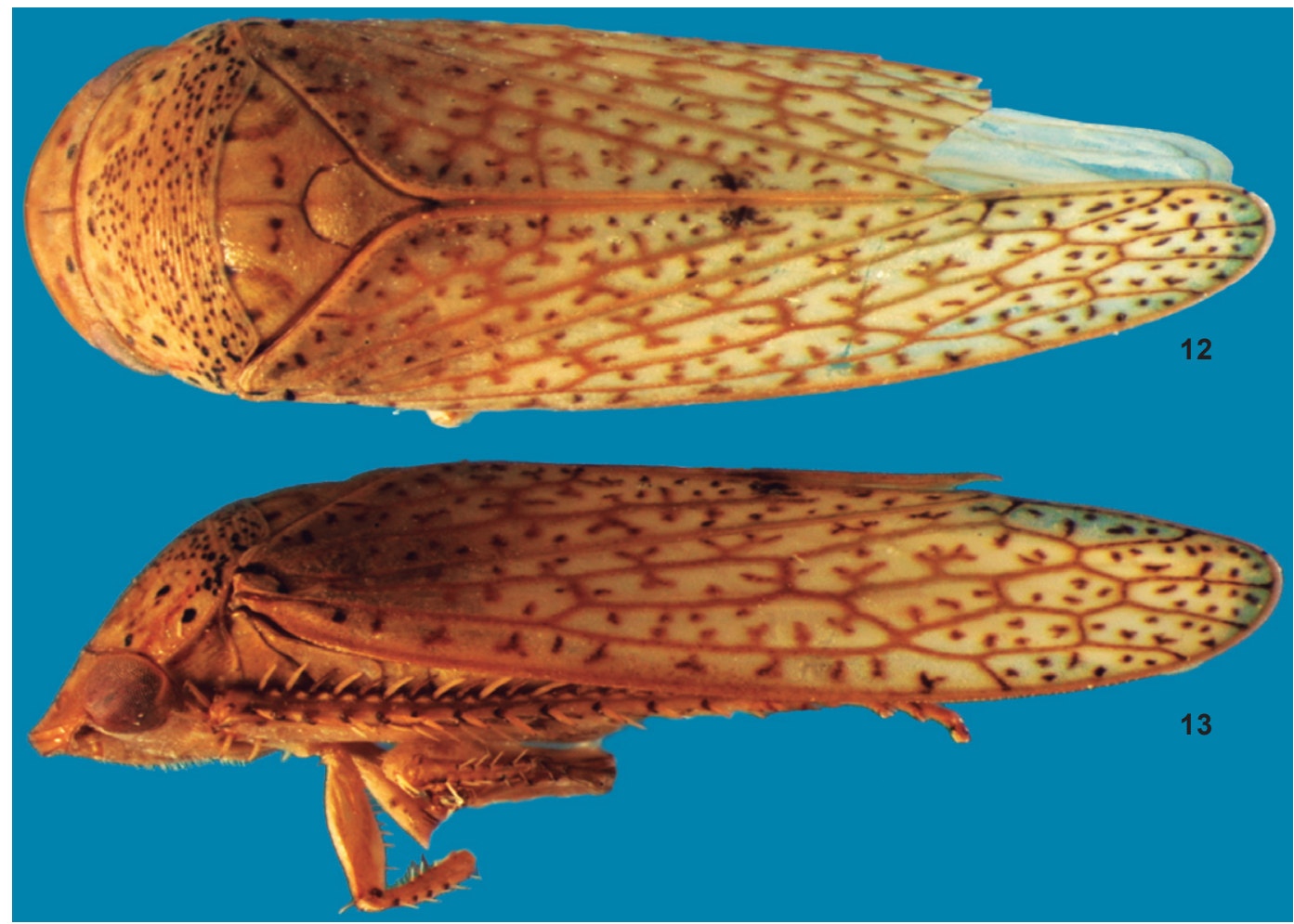

Figures 12-13. Male holotype habitus: (12) dorsal view; (13) lateral view.

longer than bifid stalk. Styles (Fig. 9), in lateral view, L-shaped, elongate and slender; ventral margin not serrated and without concavity; apex hook-shaped, curved dorsally. Aedeagus (Figs 10 and 11) elongate and robust; dorsal apodemes short and stout; pair of atrial processes turned upwards, slightly shorter than aedeagal shaft; apices acute and divergent; shaft turned posteriorly, strongly curved at base, gonopore between two apical processes, each process with outer lateral margins finely serrated subapically, apex hook-like, turned ventrally.

Coloration. Overall coloration (Figs 12 and 13) yellow with small dark spots. Crown yellow with pair of small rounded black spots between ocelli and posterior margin. Face yellow. Pronotum yellow with small punctate black spots on central portion of median third and posterior third; three rounded black spots near anterior margin just behind eyes. Mesonotum yellow with two longitudinal, elongated, dark brown spots at center and transverse dark brown crescent-like spots at anterior angles. Forewings (Fig. 4) subhyaline, with numerous scattered brown maculae, venation yellowish-brown. Legs yellow.

Material examined. Holotype male: "Peru, Madre de Dios, Sierra \de Santa Rosa 21.vii.2012 (Light) $12^{\circ} 58^{\prime} 05^{\prime \prime} \backslash 70^{\circ} 19^{\prime} 90^{\prime \prime W}$, 470 m; R. R. Cavichioli leg." [MUSM].

Etymology. The species epithet, furcata, comes from the Latin word "furcatis" and means forked. It refers to the aedeagal shaft with two apical processes.
Remarks. Arapona furcata sp. nov. shares the following characters with the other two species included in the genus: 1 ) crown broadly rounded; 2 ) crown margin thin; 3 ) ocelli nearer anterior margin of crown; (3) pronotum declivous; 5) forewing yellowish with small brown spots, 6) aedeagus with atrial processes. It can be distinguished from the other species mainly by the following features: 1) style without concavity on ventral margin; 2) aedeagus more robust than those of the previously described species, with a pair of long and slender preatrial processes, that are turned upwards, almost as long as shaft, with acute apex, and, in posterior view, divergent apically; and 3) aedeagus shaft bifid with apex hook-like. The key below is proposed based on DeLong's (1979) descriptions.

\section{Key to known species of Arapona (males)}

1. Styles with apex hook-shaped, curved dorsally; aedeagal shaft with two apical processes 2

1 '. Styles with apex only slightly curved; aedeagal shaft with four short apical processes .. Arapona vallea

2. Styles with ventral margin with concavity; aedeagus slender, preatrial processes shorter than shaft ..........Arapona devisa

2 '. Styles with ventral margin without concavity; aedeagus robust, preatrial processes almost as long as shaft Arapona furcata sp. nov. 


\section{ACKNOWLEDGEMENTS}

We thank two anonymous reviewers for providing comments and corrections on a manuscript draft of this paper. The junior author is a research fellow from Conselho Nacional de Desenvolvimento Científico e Tecnológico (CNPq, process $303.127 / 2010-4)$. This research was partially funded by PROTAX/CNPq research grants to the junior (process 561.298/ 2010-6) author and senior author (process 102184/2013-5). This paper is the contribution number XXXX of the Departamento de Zoologia, Universidade Federal do Paraná. The senior author dedicates this paper to his family and friends who supported him when it was being written, in particular Carla Burgues Floriano, who helped us to edit the illustrations, and Andressa Paladini for her valuable contribution.

\section{LITERATURE CITED}

Cavichioli, R.R. \& D.M. TakiYa. 2012. Description of a new species of Wolfniana and new records of Rotigonalia (Hemiptera: Cicadellidae: Cicadellinae) from the state of Amazonas, Brazil. Zoologia 29 (1): 85-88. doi: 10.1590/S198446702012000100011

DeLong, D.M. 1979. A new genus, Arapona, and two new species of Gyponinae (Homoptera: Cicadellidae) related to Clinonella. Ohio Journal of Science 79 (1): 45-46.
DeLong, D.M. \& P.H. Freytag. 1971. Studies of the Gyponinae: Rhogosana and four new genera, Clinonella, Tuberana, Flexana, and Declivara. Journal of the Kansas Entomological Society 44 (3): 313-324.

Hamilton, K.G.A. 1981. Morphology and evolution of the rhynchotan head (Insecta: Hemiptera, Homoptera). Canadian Entomologist 113: 953-974.

Mejdalani, G. 1998. Morfologia externa dos Cicadellinae (Homoptera, Cicadellidae): comparação entre Versigonalia ruficauda (Walker) (Cicadellini) e Tretogonia cribrata Melichar (Proconiini), com notas sobre outras espécies e análise da terminologia. Revista Brasileira de Zoologia 15: 451-544. doi: 10.1590/S0101-81751998000200015

Oman, P.W. 1949. The Nearctic leafhoppers (Homoptera: Cicadellidae). A generic classification and check list. Memoirs of the Entomological Society of Washington 3: 1-253.

RakiTov, R.A. 1997. On differentiation of cicadellid leg chaetotaxy (Homoptera: Auchenorrhyncha: Membracoidea). Russian Entomological Journal 6: 7-27.

Young, D.A. 1968. Taxonomic study of the Cicadellinae (Homoptera: Cicadellidae), Part 1, Proconiini. Bulletin of the United States National Museum 261: 1-287.

Young, D.A. 1977. Taxonomic study of the Cicadellinae (Homoptera: Cicadellidae), Part 2, New World Cicadellini and the genus Cicadella. Technical Bulletin of the North Carolina Agricultural Experiment Station 239: 1-1135.

Submitted: 06.III.2014; Accepted: 28.IV.2014.

Editorial responsibility: Gabriel L.F. Mejdalani

ZOOLOGIA 31 (3): 281-284, June, 2014 